Note

\section{Anti-inflammatory Active Constituents of Aloe arborescens Miller}

\author{
Masatoshi Yamamoto, Toshio Masui, \\ Kiyoshi Sugryama, ${ }^{* 1}$ Masami Yokota, ${ }^{* 1}$ \\ Kazuya NAKAGOMI*2 \\ and Hiroyuki NAKAZAWA*3 \\ Shizuoka Prefectural Institute of Public Health \\ and Environmental Science, 4-27-2 Kita-ando, \\ Shizuoka 420, Japan \\ ${ }^{*}$ School of Pharmaceutical Science, \\ University of Shizuoka, 395 Yada, Shizuoka 422, Japan \\ *2 Fermentation Research Institute, 1-l-3 Higashi, \\ Tsukuba, Ibaraki 305, Japan \\ ${ }^{*}$ The National Institute of Public Health, \\ 4-6-1 Shirokanedai, Minato-ku, Tokyo 108, Japan \\ Received July 16, 1990
}

Aloe arborescens Miller (Aloe; "Kidachi-aroe" in Japanese) has been widely used as a folk remedy for constipation, bites, burns, etc. in Japan. ${ }^{1,2)}$ Many constituents have been isolated from Aloe, ${ }^{3,4)}$ but no one has correlated the constituents to an anti-inflammatory activity. We have previously reported ${ }^{5)}$ that the major constituents of Aloe, barbaloin and aloenin, showed inhibitory effects on rat mast cell degranulation. This report describes the inhibitory effects of the constituents of Aloe, including barbaloin and aloenin, on carrageenan-induced rat-paw inflammatory edema.

The procedure for isolating the anti-inflammatory constituents of Aloe is shown in Chart 1. The structures of the isolated active constituents, aloenin, barbaloin, aloe-emodin, $\beta$-sitosterol and a mixture of straight-chain higher alcohols $\left(\mathrm{C}_{26}, 3.5 \% ; \mathrm{C}_{28}, 57.7 \% ; \mathrm{C}_{30}, 25.9 \% ; \mathrm{C}_{32}\right.$, $8.8 \%$ ), are shown in Fig. 1. The anti-inflammatory activity of fractions from Aloe and of the 5 isolated active constituents toward carrageenan-induced edema in rats is summarized in Table I. The original $\mathrm{MeOH}$ extract $(\mathrm{MeOH}$ ext.) showed significant inhibitory activity toward the edema. From partially purified fractions of the $\mathrm{MeOH}$ ext., the anti-inflammatory activity was detected majnly in the $n-\mathrm{BuOH}$ extract ( $n$-BuOH ext.). Frs. 1 and 2 from the $n$ - $\mathrm{BuOH}$ ext. exhibited similar activity, $45.9 \%$ and $58.2 \%$, respectively. Aloenin, barbaloin and aloe-emodin, which were isolated from Fr. 1, also significantly inhibited the edema. Among the fractions separated from Fr. 2, only Fr. 2-1 showed significant inhibitory activity toward the edema. The constituents isolated from Fr. 2-1, higher alcohols and $\beta$-sitosterol, also inhibited the edema by

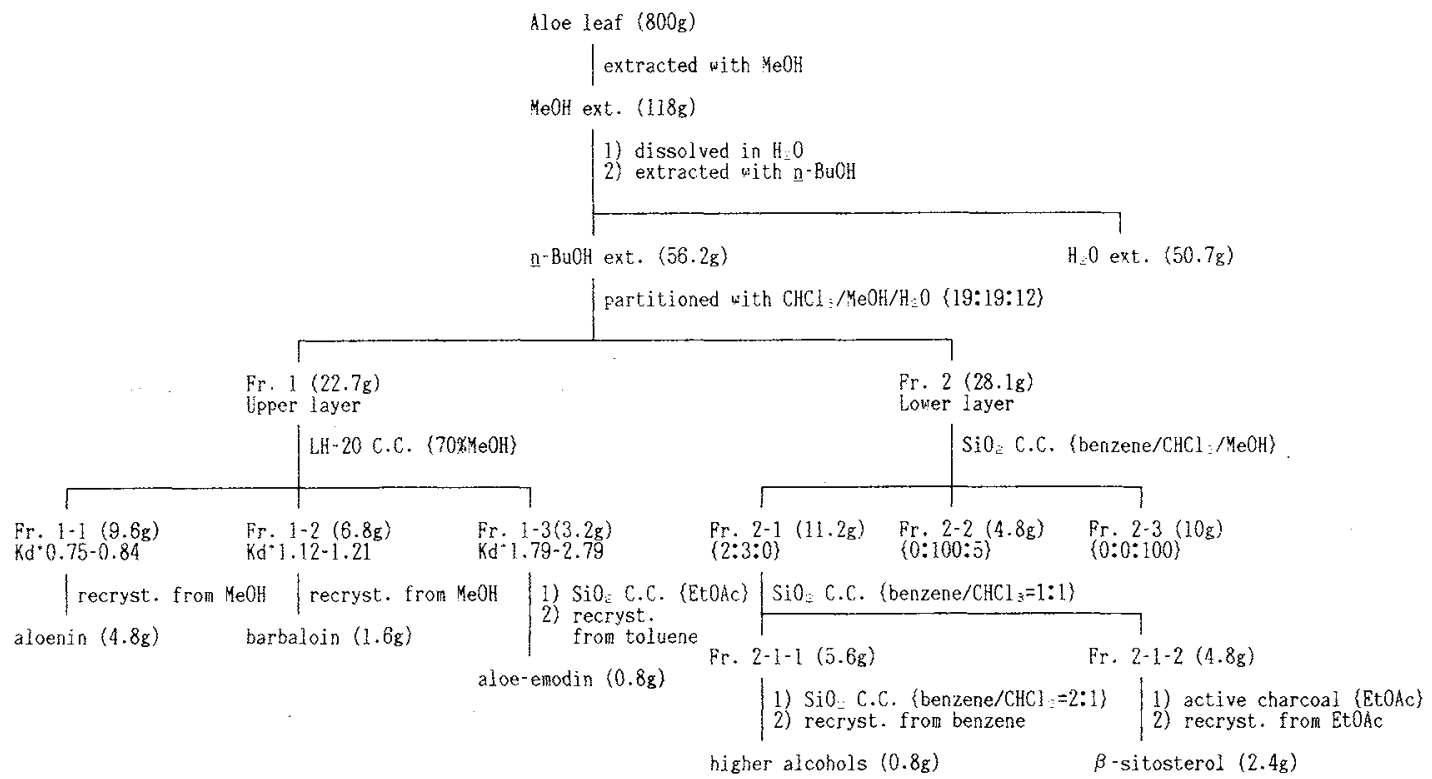

Chart 1. Isolation Procedure for the Constituents with Anti-inflammatory Activity from Aloe arborescens Miller by Monitoring Carrageenan-induced Edema in Rats.

The yield of each fraction obtained from $800 \mathrm{~g}$ of Aloe arborescens Miller is designated in parentheses.

* $K d$ (distribution constant $)=($ elution volume - void volume $) /$ internal volume 
<smiles>COc1cc(OC)cc(-c2c(C)cc(OC)cc2OC)c1</smiles><smiles>O=C1c2c(O)cccc2C(Cl)c2cc(CO)cc(O)c21</smiles>

Barbaloin<smiles>O=C1c2cc(CO)cc(O)c2C(=O)c2cccc(O)c21</smiles>

Lloe enodin

Fig. 1. Structures of 5 Isolated Constituents with Anti-inflammatory Activity from Aloe arborescens Miller.

Table I. ANTI-INFLAMmatory ACtivity OF THE FRACTIONS AND ISOLATED CONSTITUENTS FROM Aloe arborescens MILLER

\begin{tabular}{|c|c|c|c|}
\hline Test sample & $\begin{array}{c}\text { Dose } \\
\text { (mg/kg/i.p.) }\end{array}$ & $\begin{array}{c}\% \text { Swelling }{ }^{a} \\
(\text { mean }+ \text { S.E. })\end{array}$ & $\begin{array}{c}\text { Inhibition }^{b} \\
(\%)\end{array}$ \\
\hline Control & & $53.6 \pm 3.0$ & $\ldots$ \\
\hline $\mathrm{MeOH}$ ext. & 250 & $25.6 \pm 3.2^{*}$ & 52.2 \\
\hline$n$-BuOH ext. & 150 & $21.5 \pm 0.9 * * *$ & 59.9 \\
\hline $\mathrm{H}_{2} \mathrm{O}$ ext. & 150 & $38.0 \pm 2.0 * *$ & 29.1 \\
\hline Fr. 1 & 100 & $29.0 \pm 5.4^{* *}$ & 45.9 \\
\hline Fr. 2 & 100 & $22.4 \pm 3.4 * * *$ & 58.2 \\
\hline Fr. 2-1 & 50 & $30.1 \pm 0.9^{* * *}$ & 43.8 \\
\hline Fr. 2-2 & 50 & $41.0 \pm 4.6$ & 23.5 \\
\hline Fr. 2-3 & 50 & $51.1 \pm 6.1$ & 4.7 \\
\hline Control & & $60.6 \pm 4.8$ & 一 \\
\hline Aloenin & 50 & $35.5 \pm 5.3^{*}$ & 41.7 \\
\hline Barbaloin & 50 & $43.1 \pm 3.3^{*}$ & 28.8 \\
\hline Aloe-emodin & 100 & $36.4 \pm 4.4^{*}$ & 39.9 \\
\hline Higher alcohols & 50 & $23.1 \pm 3.7 * * *$ & 61.9 \\
\hline$\beta$-Sitosterol & 50 & $18.6 \pm 0.6^{* *}$ & 69.3 \\
\hline Indomethacin & 10 & $31.4 \pm 1.0^{*}$ & 48.2 \\
\hline Aspirin & 100 & $23.2 \pm 0.9 * *$ & 61.7 \\
\hline
\end{tabular}

a Significantly different from the control at $* p<0.05$; ${ }^{* *} p<0.02$, and ${ }^{* * *} p<0.001$.

${ }^{b}$ Inhibition $3 \mathrm{hr}$ after injecting carrageenan.

$61.9 \%$ and $69.3 \%$, respectively. The isolated active compounds showed almost the same inhibitory activity as that of aspirin (Table I). On the basis of their yield and activity, each of these 5 constituents is considered to account for the anti-inflammatory action of the $\mathrm{MeOH}$ ext.
We have disclosed for the first time that aloenin, barbaloin, aloe-emodin, $\beta$-sitosterol and a mixture of straight-chain higher alcohois have an inhibitory action on rat paw edema. Furthermore, we found that these compounds play an important role in the anti-inflammatory action of Aloe.

\section{Experimental}

Aloe leaves. Aloe arborescens Miller was purchased from Aloe Seiyaku Co., Ltd., Shizuoka, Japan.

Measurements. ${ }^{\mathrm{I}} \mathrm{H}-\mathrm{NMR}$ spectra were recorded at $90 \mathrm{MHz}$ on a JEOL FX-90 NMR spectrometer with TMS as an internal standard. Mass spectra were taken with a Hitachi M-80A GC-MS mass spectrometer, and IR spectra on a JASCO A-220 IR spectorophotometer. TLC was performed on precoated Kieselgel $60 \mathrm{~F}_{254}$, and the spots were visualized by spraying with a mixture of ammonium molybdate, ceric sulfate and $10 \% \mathrm{H}_{2} \mathrm{SO}_{4}$ reagent. Column chromatography was carried out with Sephadex LH-20 (25-100 $\mu \mathrm{m}$, Pharmacia LKB Ltd.) and Wakogel C-200 (74-149 $\mu \mathrm{m}$, Wako Pure Chemical Industries Ltd., Osaka, Japan).

Assay for anti-inflammatory activity. The carrageenaninduced rat inflammatory edema described by Winter et $a{ }^{6}{ }^{6}$ was used in this experiment. Ten male Wistar strain rats weighing $130-150 \mathrm{~g}$ were used at each dose level, the samples tested being administered $30 \mathrm{~min}$ before the carrageenan treatment. A subplantar injection of $0.1 \mathrm{ml}$ of $1 \%$ carrangeenan (lambda carrangeenan type IV, Sigma Chemical Co. Ltd.) in saline solution was given, the volume of the foot was measured with a Ugo Basile plethysmometer every $1 \mathrm{hr}$ for $5 \mathrm{hr}$, and the percentage swelling (foot edema) was calculated. The swelling of the paw reached a peak 3 hr after injecting the carrageenan. The results are expressed as the inhibition of swelling at $3 \mathrm{hr}$, relative to the control group given a saline solution. The significance of difference between the means of the treated and control groups in swelling was assessed by Student's $t$ test.

Structural elucidation. The structures of aloenin, barbaloin, aloe-emodin and $\beta$-sitosterol were each confirmed by comparing their MS, MNR and IR spectra with those of authentic samples. The higher alcohols were acetylated with acetic anhydride and pyridine at $140^{\circ} \mathrm{C}$ for $2 \mathrm{hr}$, subjected to GC-MS in a column ( $3 \mathrm{~mm}$ i.d. $\times 1 \mathrm{~m}$ ) packed with $2 \%$ OV-1, and identified as a mixture of straight-chain higher alcohols by comparing their mass spectra with those of authentic samples (obtained from Gasukuro Kogyo Co., Ltd., Tokyo, Japan).

Acknowledgment. We are very grateful to Professor T. Hirata of Hiroshima University for kindly supplying the data for aloenin and for evaluating our spectral data for 
aloenin. We thank Aloe Seiyaku Co., Ltd. for providing authentic barbaloin and aloe-emodin.

\section{References}

1) T. Namba, "Coloured Illustrations of WakanYaku," Vol. Il, Hoikusha Publishing Co., Ltd., Osaka, 1980, pp. 218-221.

2) S. Kameyama and K. Sugimoto, Fragrance J., 60 , I01 (1983).
3) K. Makino, A. Yagi and I. Nishioka, Chem. Pharm. Bull., 21, 149 (1973)

4) T. Hirata and T. Suga, Bull. Chem. Soc. Jpn., 51, 872 (1978).

5) K. Nakagomi, M. Yamamoto, H. Tanaka, N. Tomizuka, T. Masui and H. Nakazawa, Agric. Biol. Chem., 51, 1723 (1987).

6) C. A. Winter, E. A. Risley and G. W. Nuss, Proc. Soc. Exp. Med., 111, 544 (1962). 